\title{
Giant Thoracal Mass Spreading Transdiaphragmatically Towards Abdomen: A Case Report
}

\author{
Transdiyafragmatik Olarak Batına Doğru Yayılan Dev Torakal Kitle: Bir Olgu Sunumu
}

\author{
Ayşenur Cerrah Celayir ${ }^{1}$, Cengiz Gül ${ }^{1}$, Suna Cesur ${ }^{2}$
}

1. Zeynep Kamil Maternity and Child Diseases Training Hospital, Pediatric Surgery Clinic, Istanbul, Turkiye 2. Zeynep Kamil Maternity and Child Diseases Training Hospital, Pathology Clinic, Istanbul, Turkiye

\section{ABSTRACT}

Introduction: Childhood endodermal sinus tumors arising from the lung parenchyma are quite rare. The aim of this case presentation is to discuss the a patient with a germ cell tumor originated from thorax invading the abdomen trans- diaphragmatically.

Case: ETwo years old girl admitted with opacity in the right lung like a giant mass and opacity like a rib in this infiltration and minimal effusion in X-Ray. In an emergency thoracotomy due to respiratory distress and mediastinal shift; a giant encapsuled mass was seen in the right intrathorasic cavity; it was completely covering the right middle and lower hemithorax. The mass was penetrated and fixed into the diaphragm approximately $10 \mathrm{~cm}$ in diameter.It had penetrated towards the abdomen. The mass was separated by blunt dissections from the surrounding pleural tissues and pericardium. At the same time with the right upper subcostal incision, the mass was mobilized from the liver and gerato fascia by the blunt dissection. One cm away from the penetrating edge of diaphragm it has been incised and the mass (with thoracal part, and abdominal part, and penetrated diaphragm) totally removed via $a b-$ dominal incision through the diaphragmatic defect. Remaining edges of the diaphragm closed primarily. The histopathological diagnosis was combined malignant germ cell tumor (yolc sac tumor and mature teratoma) and she has been followed up and treated by pediatric oncology clinic. Postoperative local recurrence or metastasis was not found three years later.

Conclusion: A giant thoracal mass spreading transdiaphragmatically towards abdomen was excised succesfully via thoracotomy and laparotomy. In huge thoracal mass, removing of the mass without perforation may not be possible with just a thoracotomy; if necessary, try to avoid abdominal incision.

Keywords: mediastinum; abdomen; teratoma; endodermal sinus tumor; extragonadal germ cell tumors; neoplasia; malignancy

\footnotetext{
İletişim Bilgileri:

Yazışmadan Sorumlu Yazar: Ayşenur Cerrah Celayir

Yazışma Adresi: Zeynep Kamil Maternity and Child

Diseases Training Hospital, Pediatric Surgery Clinic,

Istanbul, Türkiye

E-mail: acelayir@ttmail.com

Makalenin Geliş Tarihi: 26.08.2014

Makalenin Kabul Tarihi: 27.01.2015
}

\section{ÖZET}

Giriș: Akciğer parenkiminden kaynaklanan çocukluk çă̆l endodermal sinus tümörleri oldukça nadirdir. Bu çalışmanın amacl, transdiyafragmatik penetrasyonu ile toraksdan batina yayilan bir germ hücre tümörlü hastanın tartışılmasıdır.

Olgu: 2 yaşında bir kız hasta ağır solunum distresi ile başvurduruldu. Akciğer grafilerinde sağ akciğerde opakt kitle görünümü, kitlenin içinde ayrica kosta șeklinde başka bir opasite ve sola mediastinal kayma mevcuttu. Ağır solunum sikıntısı ve mediastinal kayma nedeniyle yapilan acil torakotomide, săg intratorasik kaviteyi tamamen kaplayan büyük kapsüllü dev bir kitle olduğu görüldü̈. Kitle, $10 \mathrm{~cm}$ çapında geniş bir tabanla diyafragmaya sikıca yapışmış ve penetre etmişti. Eş zamanl yapılan subkostal insizyon ile batına girilerek kitle karaciğer ve Gerato kapsülünden mobilize edildi. Diyafragmada tümör penetrasyonu kenarindan $1 \mathrm{~cm}$ uzaktan yapllan insizyon ile; torakal kisim, diyafragmatik infiltrasyon kisım, abdominal kısım olmak üzere kitle tümüyle diyafragmadaki defekten aşağıya çekilerek subkostal insizyondan batın dışına alındı. Diyafragmatik defekt kenarı primer onarım yapıldi. Histopatolojik tanı, Yolk Sac tümörü ve matür teratom olmak üzere "combine malign germ hücreli tümör" idi. Hasta takip ve tedavi için pediatrik onkoloji kliniğine refere edildi. 3 ylllik takipte postoperatif lokal rekürrens veya metaztaz gözlenmedi.

Sonuç: Transdiyafragmatik olarak batına doğru yayllan bir dev torakal kitle, torakotomi ve laparotomik yoldan iki insizyonla başarıyla çıkarıldı. Dev torakal kitlelerin sadece torakotomi insizyonu ile perfore edilmeden çıkarılması her zaman mümkün olamayabilir; gereken durumlarda abdominal insizyon yapmaktan kaçınılmamalıdır.

Anahtar Kelimeler: mediasten; abdomen; teratom; endodermal sinus tümorü; extragonadal germ hücreli tümörler; neoplazi; malinite 


\section{INTRODUCTION}

Malignant germ cell tumors are subdivided into seminomas and nonseminomatous. Nonseminomatous tumors also are termed malignant teratomas and are divided further by cell type into choriocarcinomas, embryonal carcinomas, mixed tumors, teratocarcinomas, and yolk sac carcinomas. Mediastinal teratomas are the most frequent mediastinal germ cell tumors, while immature teratomas are very rare $(1,2)$. About $5-10 \%$ of all germ cell tumors are found in the mediastinum. The mediastinal teratomas can be seen in any age group but most commonly occur in adults from 20 to 40 years of age (2). In patients younger than 15 years, immature teratomas behave similarly to their mature counterparts (3). In older patients, they may behave as highly malignant tumors (4). Childhood endodermal sinus tumors arising in the lung parenchyma are quite rare. Herein we present/report a child with a germ cell tumor, which originated from thorax and invading the abdomen transdiaphragmatically.

\section{CASE REPORT}

We report a case of a massive mediastinal teratoma penetrating of diaphragm in a 2 year-old girl who presented with a short history of right thoracic mass after inflammatory period by fever and dyspnea. The x-ray documented an abnormal shadow in the right mediastinum and opacity like a rib into this infiltration and minimal effusion (Figure 1).

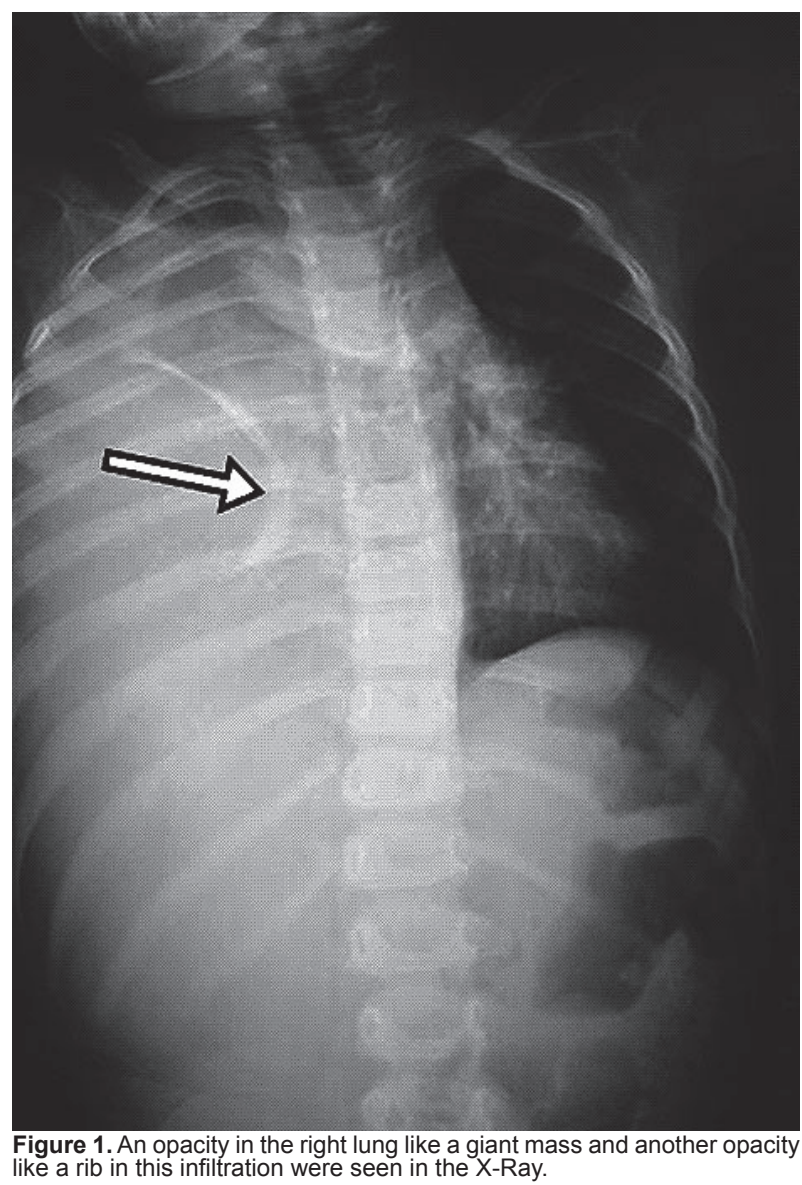

A CT-scan revealed a bulky mass of $15 \times 20 \mathrm{~cm}$ in the right side of the hemi thorax and lower mediastinal region, extended into the left pleural cavity, adherent to the diaphragm and compressing the left pulmonary. The serum alpha fetoprotein (AFP) was elevated to 3200 $\mathrm{ng} / \mathrm{ml}$ (n.v. $<8.6 \mathrm{ng} / \mathrm{ml}$ ), $\beta$-HCG and LDH were normal. In an emergency thoracotomy due to

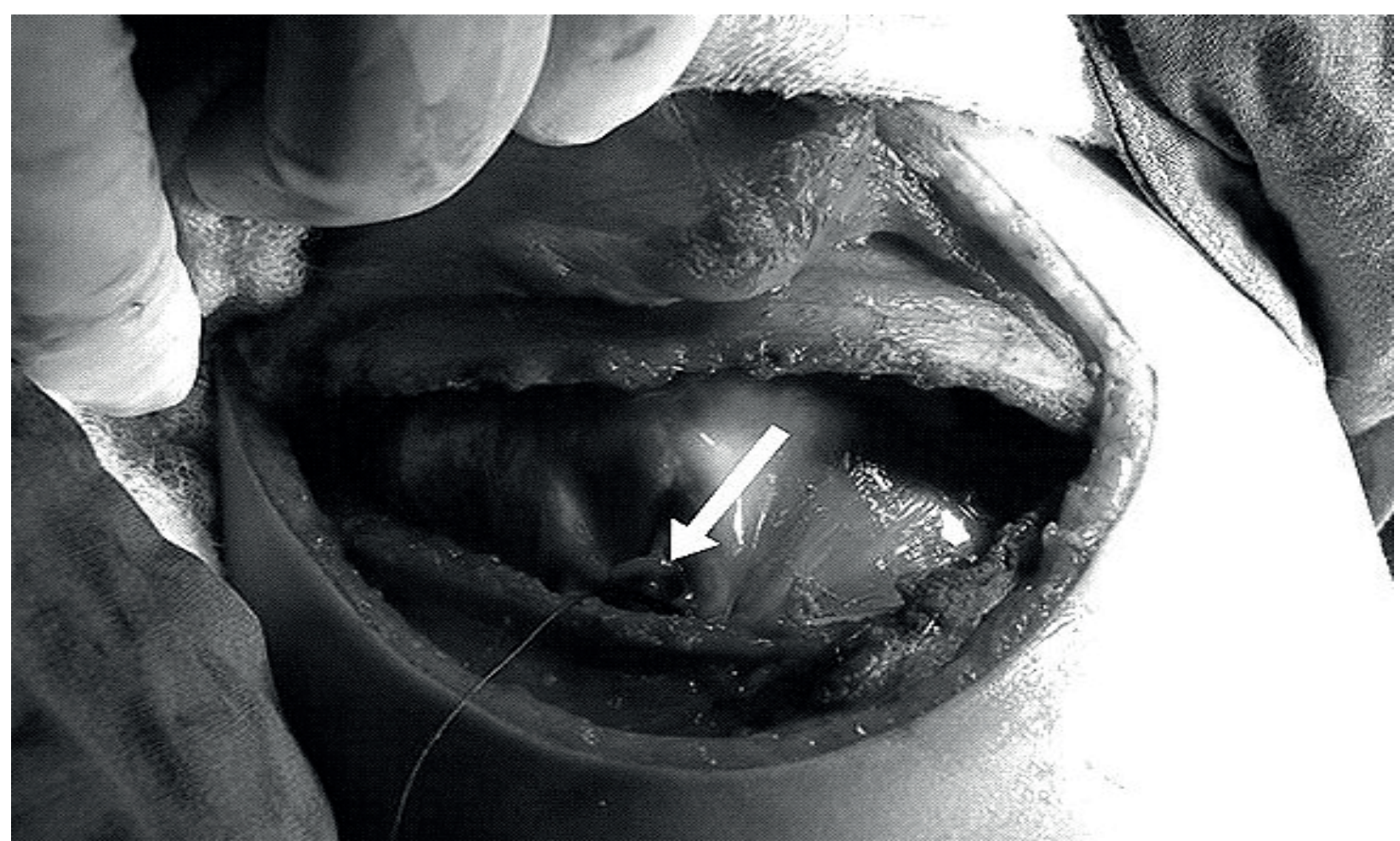




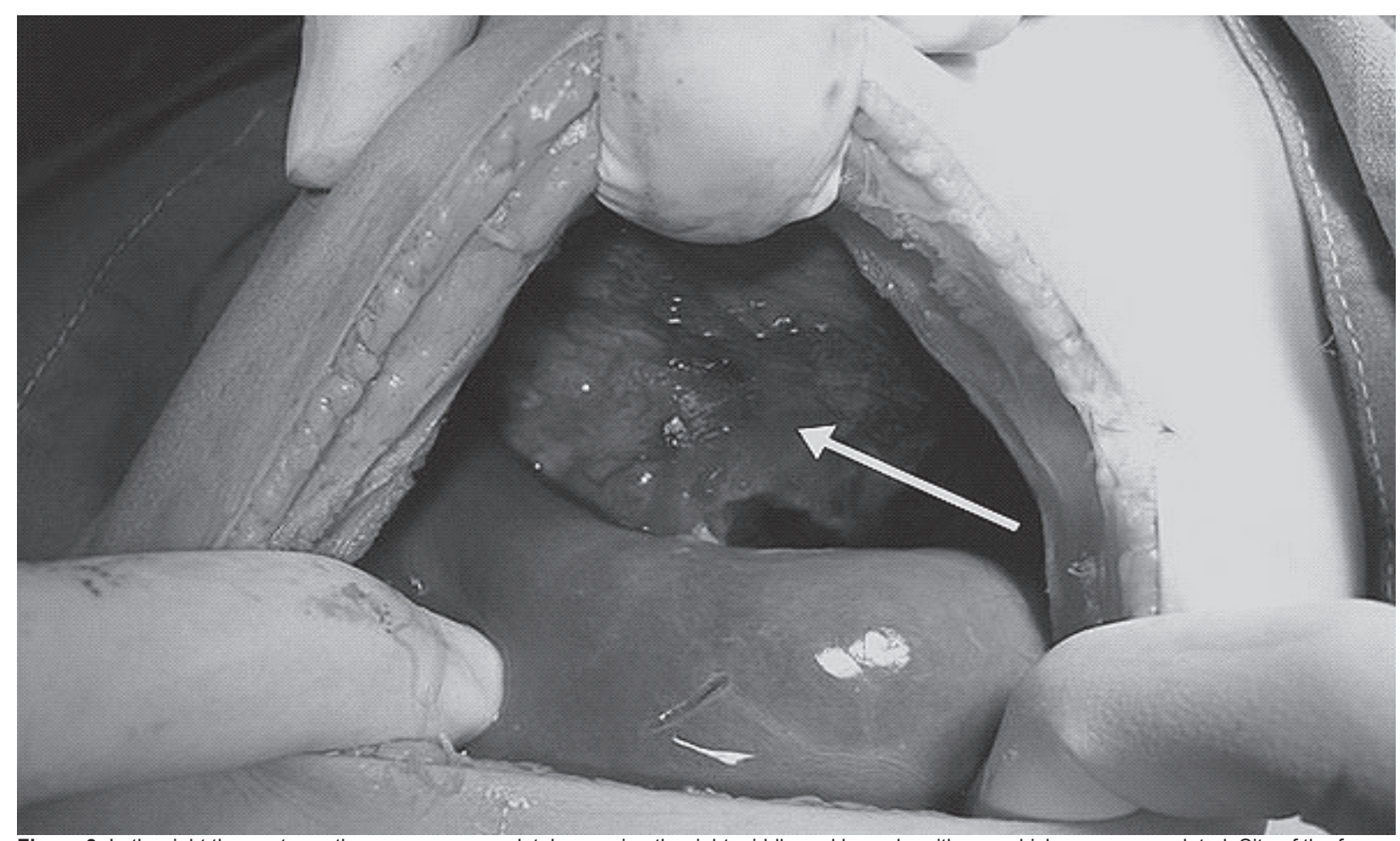

Figure 3. In the right thoracotomy, the mass was completely covering the right middle and lower hemithorax which was encapsulated. Site of the frozen biyopsi was marked with an arrow.

respiratory distress and mediastinal shift; a giant encapsuled mass was seen in the right intrathorasic cavity; it was completely covering the right middle and lower hemithorax (Figure 2). The mass was penetrated and fixed into the diaphragm approximately $10 \mathrm{~cm}$ in diameter. A biopsy was taken for frozen section. The mass was separated by blunt dissections from the surrounding pleural tissues and pericardium. At the same time, the mass was mobilized from the liver and gerato fascia with the right upper subcostal incision by the blunt dissection. Mass was also penetrated towards the abdomen from the diaphragm and burrowed to diaphragmatic face of the the liver. Mass was not fixed to liver. One $\mathrm{cm}$ away from the penetrating edge of the mass into the diaphragm has been incised and the mass (with thoracal part, and abdominal part, and penetrated diaphragm) totally removed via abdominal incision through the diaphragmatic defect. Remaining edges of the diaphragm closed primarily (Figure 3, 4).

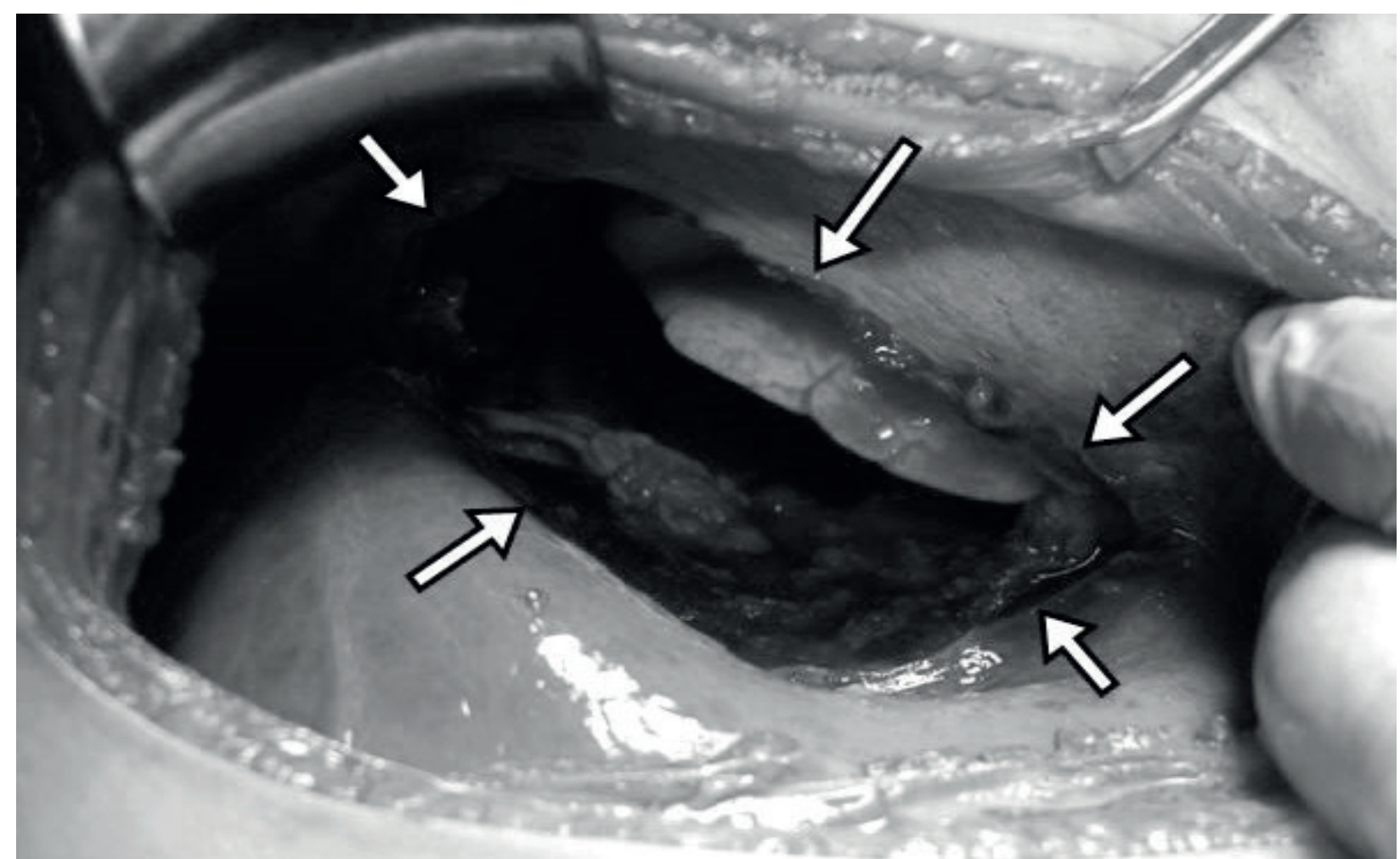

Figure 4. One $\mathrm{cm}$ away from the penetrating edge of diaphragm has been incised and the mass (throcal part, abdominal part and penetrating diaphragm) totally removed via abdominal incision through the diaphragmatic defect. The medial edge of the diaphragmatic defect was marked with arrows. 
A histopathological diagnosis was combined malignant germ cell tumor (yolc sac tumor and mature teratoma) and she has been followed up and treated by pediatric oncology clinic. After the excision, the elevated serum alpha fetoprotein (AFP) levels dropped $300 \mathrm{ng} /$ $\mathrm{ml}$ after 1 month from the surgery up to normal levels. Postoperative local recurrence or metastasis was not found three years later.

\section{DISCUSSION}

Patients older than 15 years with immature mediastinal teratomas were classified into survivor and non-survivor groups, and the characteristics in each group were evaluated (5). In the survivor group, the tumor was completely resected, or patients showing a high level of alpha-fetoprotein were treated by pre-operative chemotherapy, while the negative marker patients were treated by post-operative chemotherapy. In the non-survivor group, the tumor was resected incompletely, or no chemotherapy was performed. In patients more than 15 years old with immature mediastinal teratomas, complete surgical resection of the tumor is indispensable but the association with the chemotherapy prolongs survival.

Tumors that occur in thorax and mediastinum therefore can represent many different clinical entities and pathologic processes. An understanding of the embryology of this area, as well as the anatomic relationships of the normal structures within the mediastinum, and diaphragm is essential in the proper determination of the exact nature of a mass or tumor located in this area.

Symptoms associated with compression of some portion of the respiratory tract can be produced in adults by benign lesions as well, but this occurs much less frequently than in children. However, malignant lesions are more likely to produce signs and symptoms of obstruction and/or compression because they invade or transfix normal mediastinal structures (6).

Clinical findings commonly associated with malignancy include cough, dyspnea, stridor, and dysphagia, as well as more dramatic findings such as superior vena cava syndrome. Invasion of the chest wall or pleura by a malignant neoplasm can produce persistent pleural effusions and a significant amount of local pain. Invasion of nearby nerves within the thorax also can produce local and referred pain, as well as various other findings such as hoarseness, diaphragmatic paralysis, Horner syndrome, and even motor paralysis (6). Nonspesific medical treatment of upper respiratory tract infection in our case, plain X-ray was not seen in early period in other centers. When severe respiratory distress, cough, dyspnea, stridor, and dysphagia were progressed, first $\mathrm{x}$-rays were seen two months later. Because any imagination had got before, progression time of the mass was not known in that case, groving of the mass should be taken to a long time, ther was probably born.

Complete surgical resection is indicated for thoracal teratomas. A median sternotomy, mini-sternotomy, posterolateral thoracotomy, hemiclamshell thoracotomy with or without neck extension, clamshell, and video-assisted thoracic surgery (VATS) are all described as methods for resection. Additional resection is needed according to adherent structures when teratomas are adherent. Involvement of associated intrathoracic structures by tumor may mandate their resection.

Pulmonary resection, excision of nervous structures (eg, phrenic, vagus, sympathetic chain), or even resection of major vascular structures (eg, superior vena cava) or a part of the diaphragm may be required $(6,7,8,9)$. In our case a giant thoracal mass spreading transdiaphragmatically towards abdomen, involvement of associated intrathoracic structures eg pericardium, pleura and diphragma by tumor has been mandatet their resection. Pleural and pericardial adhesion of mass easily separated, but extensive resection a part of the right diphragma had been required due to invasion of the tumor in our case.

For mature and differentiated teratomas the radical surgical removal is the only curative treatment, because unnecessary delay may result in the rupture of tumors or in malignant degeneration or penetration adjacent organs. The prognosis after surgical removal of the tumor is good and there is no recurrence of tumor after complete excision (7). For immature teratomas the main options are primary resection and chemotherapy $(8,9)$. Prognosis after resection of a mediastinal tumor varies widely depending on the type of lesion resected. After resection of mediastinal cysts and benign tumors, prognosis generally is excellent. Germ cell tumors included in this group are benign teratomas or dermoid cysts. Prognosis after treatment of ma- 
lignant mediastinal tumors depends upon the type of lesion, its biological behavior, and the extent of the disease present $(6,7,8,9)$. Histopathological diagnosis was combined malignant germ cell tumor (yolc sac tumor and mature teratoma) in our case; and patient has been followed up and treated by a pediatric oncology department of another center. Postoperative local recurrence or metastasis was not found three years later. Total removal of the mass, the prognosis has improved in that case.

In conclusion, mediastinal teratomas penetrated diaphragm is very rare in children and frequently is not diagnosed before operation. In huge thoracal mass, removing of the mass without perforation may not be possible with just a thoracotomy; if necessary, try to avoid abdominal incision. In that case, Giant thoracal mass spreading transdiaphragmatically towards abdomen was excised succesfully via thoracotomy and laparotomy. Thoracotomy and laparotomy need for excellent exposure in mediastinal tumors penetrated diaphragm.

\section{KAYNAKLAR}

1. Dulmet EM, Macchiarini P, Suc B, et al. Germ cell tumors of the mediastinum: a 30 years experience. Cancer. 1993; 72 . 1894-1901.

2. Arai $K$, Ohta S, Suzuki M, et al. Primary immature mediastinal teratoma in adulthood. Eur J Surg Oncol. 1997; 23: 64-67.

3. Moeller KH, Rosado-de-Christenson ML, Templeton PA. Mediastinal mature teratoma: imaging features. AJR Am J Roentgenol. 1997; 169: 985-990.

4. Hiroshima K, Toyozaki T, Iyoda A, et al. Apoptosis and proliferative activity in mature and immature teratomas of the mediastinum. Cancer. 2001; 92: 1798-1806.

5. Lakhoo K, Boyle M, Drake DP. Mediastinal teratomas: review of 15 pediatric cases. J Pediatr Surg. 1993; 28: 1161-1164.

6. Mueller DK. Teratomas and Other Germ Cell Tumors of the Mediastinum Annals of Oncology. 2004, 15: 1377-1399.

7. Smahi M, Achir A, Chafik A, et al. Mature teratoma of the mediastinum. Ann Chir. 2000; 125: 965-971.

8. Iyoda A, Hiroshima K, Yusa T, et al. The primary mediastinal growing teratoma syndrome. Anticancer Res. 2000; 20: 37233726.

9. Mc Leod NP, Vallely MP, Mathur MN. Massive immature mediastinal teratoma extending into the left pleural cavity. Heart Lung Circ. 2005; 14: 45-47. 